EDUTECH : Jurnal Inovasi Pendidikan Berbantuan Teknologi

Vol. 2 No. 1 Februari 2022, e-ISSN : 2797-0140 | p-ISSN : 2797-0590

\title{
PENGARUH PENGGUNAAN HANDPHONE TERHADAP KEDISIPLINAN SHALAT LIMA WAKTU SISWA KELAS V DI MADRASAH IBTIDAIYAH TERPADU LAILATUL QODAR SUKOHARJO TAHUN PELAJARAN 2020/2021
}

\author{
ANIK YUNIANINGSIH, SUHADI, INTAN AYU WULANDARI, ALFIAN EKO \\ ROCHMAWAN \\ Fakultas Tarbiyah, Institut Islam Mamba'ul 'Ulum Surakarta \\ e-mail: aanikyunianingsih@gmail.com
}

\begin{abstract}
ABSTRAK
Penelitian ini mengkaji tentang pengaruh penggunaan handphone terhadap kedisiplinan shalat lima waktu siswa kelas V di MI Terpadu Lailatul Qodar Sukoharjo Tahun Pelajaran 2020/2021. Penelitian ini menggunakan penelitian kuantitatif dengan pendekatan korelasi. Sumber data penelitian ini adalah Kepala Sekolah, Wali Kelas, Guru Agama Islam dan Siswa kelas V. Teknik pengumpulan data berupa kuesioner (angket), dokumentasi dan wawancara. Kesimpulan dari peneliti adalah sebagai berikut: 1) penggunaan handphone siswa kelas V di MI Terpadu Lailatul Qodar Sukoharjo dikategorikan cukup dengan nilai 68. 2) Tingkat kedisiplinan shalat lima waktu siswa kelas V dikategorikan cukup dengan nilai 77. 3) Terdapat pengaruh yang signifikan diantara penggunaan handphone terhadap kedisiplinan shalat lima waktu siswa kelas V dan terbukti kebenarannya.
\end{abstract}

Kata Kunci: Pengaruh, Penggunaan Handphone, Kedisiplinan Shalat Lima Waktu

\section{ABSTRACT}

This study examines the effect of using mobile phones on the discipline of five daily prayers for fifth grade students at MI Terpadu Lailatul Qodar Sukoharjo for the 2020/2021 academic year. This study uses quantitative research with a correlation approach. The data sources of this research were the principal, homeroom teacher, Islamic religion teacher and fifth grade students. Data collection techniques were in the form of questionnaires, documentation and interviews. The conclusions of the researchers are as follows: 1) the use of mobile phones for fifth grade students at MI Terpadu Lailatul Qodar Sukoharjo is categorized as sufficient to get an average score of 68.2) The level of discipline in praying five times for fifth grade students is categorized as sufficient to get an average score of 77.3) There is a significant effect between the use of mobile phones on the discipline of the five daily prayers of fifth grade students and the truth is proven.

Keywords: Influence, Cellphone Use, Five Times Prayer Discipline

\section{PENDAHULUAN}

Perkembangan teknologi informasi dan komunikasi pada Indonesia semakin berkembang. Akibatnya tanpa disadari perkembangan teknologi sudah mempengaruhi aspek kehidupan manusia. Teknologi telah menjadi kebutuhan pokok manusia dalam menjalani aktivitas. Dari Gouzali pada bukunya Sistem Telekomunikasi di Indonesia adalah Terminal telepon yang bisa dipindah-pindah. Handphone sudah menjadi alat komunikasi yang sangat krusial. Penggunaan alat komunikasi jarak jauh yang sangat efektif dan efesien. Handphone yang awalnya adalah barang langka dan hanya masyarakat kelas atas yang memilikinya, seiring perkembangan zaman yang semakin maju, sekarang Handphone menjadi barang primer serta mudah untuk didapatkan (Saydam, G., 2006: 34). Menurut Dimitri Mahyana (Dosen Sekolah Teknik Elektro dan Informatika ITB) juga menjelaskan bahwa total pengguna seluler pada indonesia meningkat sangat pesat pada tahun 2019 sekitar 265,3 juta dan 140,4 juta pengguna smartphone, sementara untuk pengguna internet sekitar 89,4 juta (Kamel Setia Permana).

Handphone sangat diminati masyarakat karena memiliki ukuran yang kecil sehingga mudah dibawa kemana saja, dan juga memiliki kemampuan hampir sama dengan komputer. Kemudian juga ditunjang dengan harga handphone yang lebih murah, sehingga terjangkau oleh 
setiap lapisan masyarakat, dan cara penggunaanya cukup mudah untuk generasi sekarang ini (Faiza, A., Firda, S.J., 2018: 29). Generasi sekarang tumbuh dan berkembang dengan keadaan masyarakat yang bergantung pada adanya teknologi, sehingga bukan suatu hal baru juka mengetahui dalam usia yang sangat belia seseorang sangat terampil dalam menggunakan handphone (Pratama, H.C., 2012: 35).

Handphone dapat diartikan suatu barang atau benda yang dipakai sebagai sarana komunikasi baik itu berupa, lisan maupun tulisan, untuk penyampaian informasi atau pesan dari suatu pihak kepihak lainnya secara efektif dan efesien karena perangkatnya yang bisa dibawa kemana-mana dan dapat dipakai dimana saja.

Zaman dulu Handphone hanya dipakai untuk menelepon dan menerima telepon serta mengirim dan menerima Short Message Service (SMS), tetapi sekarang sudah dilengkapi dengan berbagai Fitur yang dimasukkan kedalam Handphone mulai dari audio dan video, oleh sebab itu bisa mengirim gambar dan suara. Fungsi Handphone semakin berkembang jika dibarengi dengan adanya internet, karena saat ini kita telah memasuki era milenium ketiga atau disebut juga sebagai era internet. Agoeng Noegroho dalam bukunya Teknologi Komunikasi menyebutkan bahwa internet merupakan "Sumber daya informasi yang berorientasi ke manusia". Internet memberikan kesempatan pada pemakai seluruh dunia untuk mempergunakan sumber daya informasi tersebut secara bersama-sama (Agoeng, N, 2010: 2).

Menurut Sutarman dalam buku Pengantar Teknologi Informasi, menyebutkan bahwa internet merupakan hubungan antar berbagai jenis komputer dan jaringan di dunia yang berbeda sistem operasi maupun aplikasinya, yang mana hubungan tersebut memanfaatkan kemajuan media komunikasi (telepon dan satelit) dengan menggunakan protokol estándar saat berkomunikasi, bernama protokol TCP/IP (Sutarman, 2009: 27).

Penggunaan Handphone memberikan dampak positif dan negatif bagi penggunanya, bukan hanya orang dewasa namun sudah masuk pada dunia remaja bahkan anak kecil. Seperti halnya siswa - siswi MI Terpadu Lailatul Qodar Sukoharjo khususnya kelas V yang sudah mengenal Handphone. Walaupun mereka tidak membawa Handphone ke sekolah, tetapi ketika di rumah mereka sering menggunakan Handphone. Ada yang menggunakannya untuk mencari materi - materi yang berhubungan dengan pelajaran, berkomunikasi di media sosial seperti facebook dan Instagram atau bermain game di Handphone. Kegemaran memainkan Handphone bisa saja menyita waktu pelajar untuk beribadah, belajar, dan mengerjakan tugas rumah. Ditambah lagi jika tidak adanya pengawasan dari orang tua di rumah dalam menggunakan Handphone. Namun, mungkin ada juga siswa yang pintar membagi waktunya antara ibadah, belajar,dan bermain Handphone.

Dalam tulisan Dedy Susanto pada jurnalnya yang berjudul "Pengguna Smartphone Dan Locus Of Countrol : Keterkaitannya Dengan Prestasi Belajar, Kualitas Tidur, dan Subjective Well-Being" menuliskan bahwa penggunaan handphone sehari-hari, mempengaruhi waktu penggunaan handphone pada saat yang tidak tepat, juga dapat mempengaruhi kualitas tidur peserta didik dan akhirnya memberi pengaruh terhadap prestasi peserta didik tersebut (Susanto, D., 2018: 12). Dampak positif yang bisa dilihat dalam penelitian ini peserta didik menggunakan Handphone untuk mencari materi yang berkaitan dengan pelajaran, berkomunikasi di media sosial dan bermain game. Tentunya kegemaran bermain Handphone yang berlebihan dapat menggangu waktu untuk beribadah, belajar dan mengerjakan tugas rumah. Kedisiplinan shalat lima waktu menjadi salah satu indikasi dampak penggunaan Handphone bagi peserta didik. Penggunaan Handphone bagi peserta didik harus selalu ada pengawasan orang tua di rumah.

Menurut Arikunto (2013: 114), kedisiplinan adalah suatu bentuk yang berkenaan dengan pengendalian diri seseorang terhadap bentuk-bentuk aturan. Peraturan dimaksud dapat ditetapkan oleh orang yang bersangkutan maupun orang lain. Kedisiplinan adalah suatu kondisi dimana seseorang mematuhi dan melaksanakan ketentuan, tata tertib, peraturan, nilai serta kaidah yang berlaku dengan kesadaran diri tanpa ada paksaan.Shalat merupakan bagian yang tak terpisahkan dari disiplin dan barang siapa yang berdisiplin, maka dialah yang sukses. Di samping itu, shalat dapat memberikan ketentraman dan ketabahan hati, sehingga tidak mudah 
Vol. 2 No. 1 Februari 2022, e-ISSN : 2797-0140 | p-ISSN : 2797-0590

putus asa dan gelisah jiwanya tatkala musibah menimpa dan tidak mudah lupa daratan bila sedang memperoleh kebahagiaan dan kenikmatan. Berdasarkan fakta tersebut, penulis melakukan penelitian untuk membahas "Pengaruh Penggunaan Handphone Terhadap Kedisiplinan Shalat Lima Waktu Siswa Kelas V di Madrasah Ibtidaiyah Terpadu Lailatul Qodar Sukoharjo Tahun 2020/2021".

\section{METODE PENELITIAN}

Penelitian ini adalah penelitian kuantitatif yang mengunakan pendekatan korelasi. Penelitian korelasi yaitu penelitian yang bertujuan mengetahui hubungan antara dua variabel. Jenis penelitian yang digunakan merupakan penelitian lapangan (field research).

Dalam penelitian ini menggunakan teknik pengumpulan data yang berupa kuesioner (Angket), dokumentasi dan wawancara. Populasi dalam penelitian ini diantaranya siswa kelas $\mathrm{V}$ yang berjumlah 45 orang. Dengan jumah sampel kurang dari 100, maka penelitian ini akan mengambil semua sampel sehingga disebut juga sebagai penelitian populasi.

Pada penelitian ini variabel bebasnya yaitu pengaruh penggunaan Handphone, dengan indikator: a) Kepemilikan Handphone, b) Waktu penggunaan Handphone, c) Aplikasi yang digunakan, d) Tujuan Penggunaan Handphone, e) Objek penggunaan Handphone dan e) Musik dan game. Sedangkan variabel terikatnya yaitu kedisiplinan shalat lima waktu, dengan indikator: a) Waktu shalat tepat waktu, b) Kesempurnaan syarat dan rukun shalat, c) Bacaan shalat, d) Konsisten dalam melaksanakan shalat lima waktu, e) Tujuan shalat, f) Kesadaran shalat, g) Dzikir dan Do'a dan h) Shalat sunah.

Teknik pengumpulan data menggunakan kuisioner (angket), dokumentasi dan wawancara. Dan analisis data merupakan upaya mengolah data menjadi informasi, sehingga karakteristik atau sifat-sifat data tersebut dapat dengan mudah dipahami dan bermanfaat untuk menjawab masalah-masalah yang berkaitan. Proses analisa data dilakukan dengan menyusun tabel distribusi frekuensi dan menggunakan teknik analisis statistik untuk membuktikan fakta empiris dengan fakta teoritis. Analisis lanjut untuk membuktikan antara fakta empiris dengan fakta teoritis. Dalam hal ini akan menggunakan analisis dengan rumus Product Momen

\section{HASIL DAN PEMBAHASAN}

Pendeskripsian hasil penelitian ini disajikan dalam bentuk angket yang dibagikan kepada siswa kelas V yang dibantu wali kelas. Hasil klasifikasi data angket yang bersifat kualititif diangkakan menjadi data kuantitatif dengan jumlah 44 peserta didik. Dengan keterangan 1) Alternatif jawaban A yang mencerminkan selalu diberi bobot angka 4, 2) Alternatif jawaban B yang mencerminkan sering diberi bobot angka 3, 3) Alternatif jawaban C yang mencerminkan kadang-kadang diberi bobot angka 2,4) Alternatif jawaban D yang mencerminkan tidak pernah diberi bobot angka 1 .

\section{Hasil}

\section{Data Penggunaan Handphone Siswa kelas V MI Terpadu Lailatul Qodar Sukoharjo}

\section{Tabel 1. Data Nilai Angket Penggunaan Handphone Siswa Kelas V} MI Terpadu Lailatul Qodar

\begin{tabular}{|c|c|c|c|c|c|c|c|c|c|c|c|c|c|c|c|c|c|c|c|c|c|c|c|c|c|c|c|c|}
\hline \multirow[t]{2}{*}{ NO } & \multirow[t]{2}{*}{ Nama } & \multirow[t]{2}{*}{ Kelas } & \multicolumn{25}{|c|}{ Butir Soal } & \multirow[b]{2}{*}{ Total } \\
\hline & & & 1 & 2 & 3 & 4 & 5 & 6 & 7 & 8 & 9 & 10 & & & & & & & 17 & 18 & & 20 & 212 & & 23 & & 25 & \\
\hline 1 & Adelya Chandra Juniasih & VA & 1 & 3 & 3 & 2 & 3 & 2 & 4 & 3 & 2 & 1 & 4 & 2 & 3 & 4 & 4 & 4 & 2 & 3 & 2 & 3 & 2 & 1 & 2 & 2 & 3 & 65 \\
\hline 2 & Adinda Keysa Kurniavi & VA & 1 & 3 & 4 & 2 & 4 & 3 & 4 & 3 & 2 & 1 & 4 & 2 & 2 & 4 & 2 & 4 & 2 & 4 & 2 & 3 & 3 & 2 & 2 & 2 & 2 & 67 \\
\hline 3 & Ailsa Bernadine Fara Putri & VA & 1 & 2 & 3 & 2 & 3 & 3 & 4 & 3 & 3 & 2 & 3 & 3 & 4 & 4 & 2 & 3 & 2 & 2 & 2 & 3 & 3 & 3 & 2 & 3 & 3 & 68 \\
\hline 4 & Amelia Fatihah Nur Q & $\overline{\mathrm{VA}}$ & 3 & 4 & 3 & 2 & 4 & 3 & 4 & 4 & 2 & 2 & 4 & 2 & 2 & 4 & 2 & 2 & 2 & 2 & 2 & 3 & 2 & 2 & 2 & 2 & 3 & 67 \\
\hline 5 & Amira Rafa Maritza & VA & 3 & 3 & 4 & 2 & 4 & 3 & 4 & 4 & 2 & 2 & 3 & 2 & 2 & 4 & 1 & 2 & 2 & 2 & 2 & 3 & 2 & 2 & 1 & 1 & 4 & 64 \\
\hline & Anggreta Evalyana Ardeka & VA & 1 & 4 & 4 & 4 & 4 & 3 & 4 & 4 & 3 & 2 & 4 & 4 & 4 & 4 & 4 & 3 & 2 & 4 & 4 & 3 & 2 & 2 & 4 & 2 & 3 & 82 \\
\hline 7 & Chelsea Althofunnisa A & VA & 1 & 3 & 3 & 2 & 4 & 3 & 3 & 4 & 4 & 1 & 3 & 1 & 4 & 4 & 3 & 3 & 2 & 1 & 2 & 3 & 2 & 1 & 3 & 1 & 4 & 65 \\
\hline 8 & Dannis Gisella Casyafani & VA & 1 & 3 & 4 & 2 & 3 & 3 & 4 & 4 & 2 & 1 & 4 & 2 & 3 & 4 & 2 & 4 & 2 & 4 & 2 & 3 & 3 & 2 & 3 & 2 & 2 & 69 \\
\hline
\end{tabular}


EDUTECH : Jurnal Inovasi Pendidikan Berbantuan Teknologi Vol. 2 No. 1 Februari 2022, e-ISSN : 2797-0140 | p-ISSN : 2797-0590

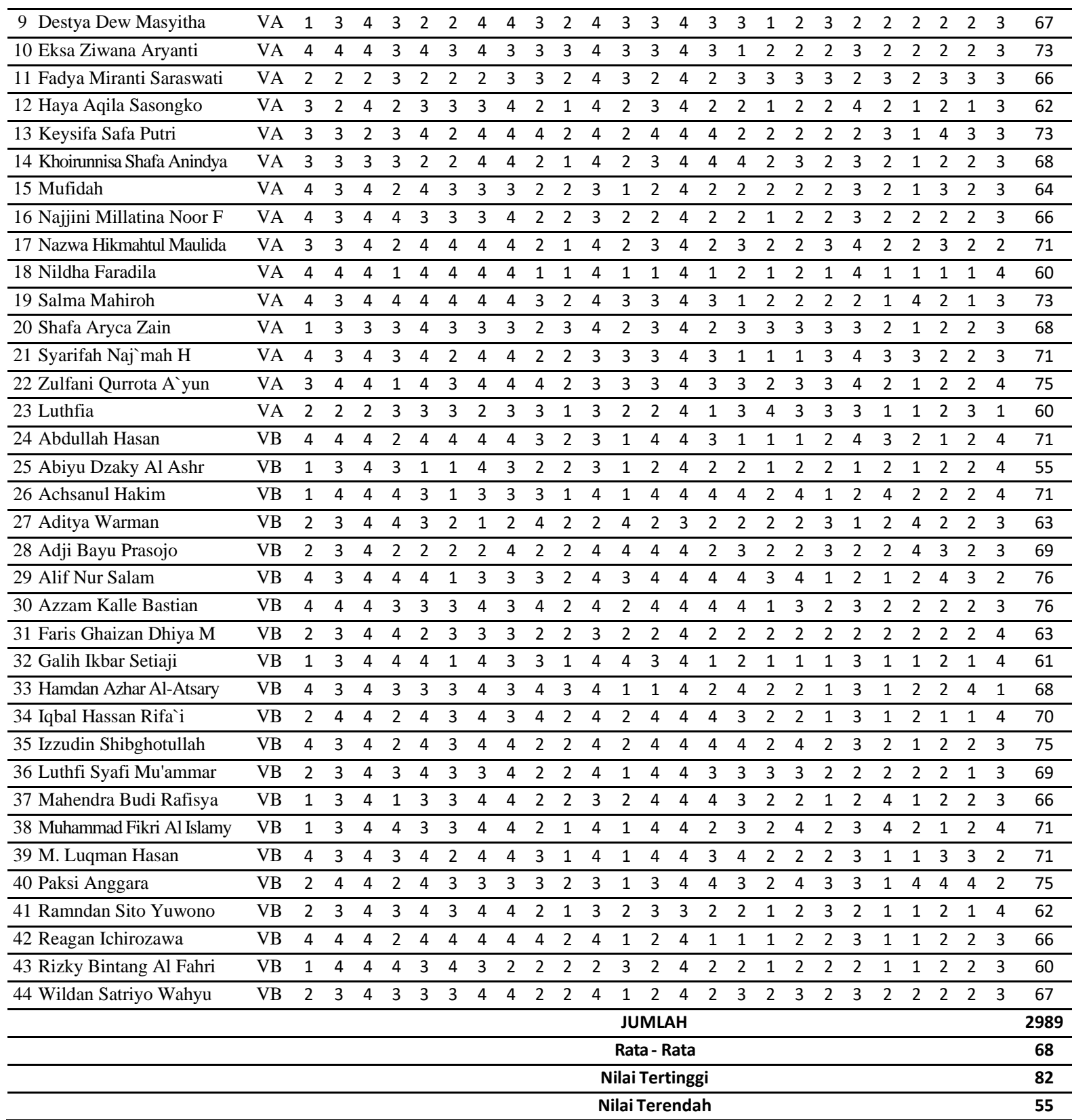

Hasil klasifikasi penelitian ini berupa angket tertutup dengan 4 (empat) alternative jawaban disesuaikan dengan keadaan peserta didik. Berikut akan disajikan hasil tes peserta didik.

Tabel 2. Perolehan Skor Hasil data angket penggunaan Handphone Kelas V

\begin{tabular}{|c|c|c|c|c|c|c|c|c|}
\hline $\begin{array}{c}\text { No } \\
\text { Kelas }\end{array}$ & $\begin{array}{c}\text { Kelas } \\
\text { Interval }\end{array}$ & $\begin{array}{l}\text { Frekuensi } \\
\text { (f) }\end{array}$ & $\begin{array}{l}\text { Frekuensi } \\
\text { kumulasi }\end{array}$ & $\begin{array}{l}\text { mid point } \\
\text { (d) }\end{array}$ & f.d & $(\mathbf{x}-\mathbf{x})$ & $(x-x)^{2}$ & f. $(x-x)^{2}$ \\
\hline 1 & $55-59$ & 1 & 1 & 57 & 57 & -11 & 121 & 121 \\
\hline 2 & $60-64$ & 10 & 11 & 62 & 620 & -6 & 36 & 360 \\
\hline 3 & $65-69$ & 17 & 28 & 67 & 1139 & -1 & 1 & 17 \\
\hline 4 & $70-74$ & 10 & 38 & 72 & 720 & 4 & 16 & 160 \\
\hline 5 & $75-79$ & 5 & 43 & 77 & 385 & 9 & 81 & 405 \\
\hline 6 & $80-84$ & 1 & 44 & 82 & 82 & 14 & 196 & 196 \\
\hline \multicolumn{2}{|c|}{ Jumlah } & 44 & \multicolumn{2}{|c|}{ Jumlah } & 3003 & \multicolumn{2}{|c|}{ Jumlah } & 1259 \\
\hline
\end{tabular}


EDUTECH : Jurnal Inovasi Pendidikan Berbantuan Teknologi

Vol. 2 No. 1 Februari 2022, e-ISSN : 2797-0140 | p-ISSN : 2797-0590

Tabel 3. Kualitas Tingkat Penggunaan Handphone Siswa Kelas V

\begin{tabular}{cccc}
\hline Interval & Frekuensi & Prosentase & Kategori \\
\hline 75,5 ke atas & 3 & $\frac{3}{44} \times 100=6,8 \%$ & Sangat Baik \\
\hline $75,5-70,5$ & 12 & $\frac{12}{44} \times 100=27,2 \%$ & Baik \\
\hline $70,5-65,5$ & 16 & $\frac{16}{44} \times 100=36,3 \%$ & Cukup \\
\hline $65,6-60,5$ & 9 & $\frac{9}{44} \times 100=20,4 \%$ & Kurang \\
\hline Kurang 60,5 & 4 & $\frac{4}{44} \times 100=9,0 \%$ & Sangat Kurang \\
\hline
\end{tabular}

Dengan demikian dapat diketahui bahwa nilai rata-rata penggunaan handphone siswa kelas V di MI Terpadu Lailatul Qodar Sukoharjo Tahun Pelajaran 2020/2021 adalah 68 dengan kategori cukup. Sehingga jika diprosentasekan dengan 44 responden menunjukkan kategori prosentase sangat baik 6,8\% dengan frekuensi 3 orang, baik 27,2\% dengan frekuensi 12 orang, cukup 36,3\% dengan frekuensi 16 orang, kurang 20,4\% dengan frekuensi 9 orang dan sangat kurang 9,0\% dengan frekuensi 4 orang.

Untuk kategori sangat kurang dalam penggunaan handphone siswa kelas V di MI Terpadu Lailatul Qodar Sukoharjo Tahun Pelajaran 2020/2021 dikarenakan anak sudah dibelikan handphone sendiri oleh orangtuanya serta kurangnya pendampingan orangtua ketika anak bermain handphone.

\section{Data Kedisiplinan Shalat Lima Waktu Siswa kelas V MI Terpadu Lailatul Qodar Sukoharjo}

Tabel 4. Data Nilai Angket Kedisiplinan Sholat Lima Waktu Kelas V MI Terpadu Lailatul Qodar

\begin{tabular}{|c|c|c|c|c|c|c|c|c|c|c|c|c|c|c|c|c|c|c|c|c|c|c|c|c|c|c|}
\hline \multirow[t]{2}{*}{ NO } & \multirow[t]{2}{*}{ Kelas } & \multicolumn{24}{|c|}{ Butir Soal } & \multirow[b]{2}{*}{ Total } \\
\hline & & 1 & 2 & 3 & 4 & 5 & 6 & 7 & 8 & 9 & & & & & & & & & & 19 & & & & & 425 & \\
\hline 1 Adelya Chandra Juniasih & VA & 3 & $\overline{2}$ & 3 & 3 & 4 & 2 & 2 & & 4 & 4 & 3 & 4 & 4 & 2 & 2 & 4 & 4 & $\overline{4}$ & 4 & 4 & 2 & 4 & 3 & 3 & 80 \\
\hline 2 Adinda Keysa Kurniavi & VA & 4 & 3 & 3 & 4 & 3 & 4 & 3 & 4 & 4 & 4 & 1 & 4 & 4 & 4 & 4 & 4 & 4 & 4 & 4 & 4 & 4 & 4 & 4 & 3 & 91 \\
\hline 3 Ailsa Bernadine Fara Putri & VA & 3 & 4 & 1 & 4 & 2 & 4 & 3 & 4 & 4 & 4 & 2 & 4 & 3 & 3 & 3 & $\overline{4}$ & 4 & 3 & 2 & 4 & 2 & 3 & 4 & 2 & 78 \\
\hline 4 Amelia Fatihah Nur Q & VA & 3 & 2 & 2 & $\overline{3}$ & 3 & 2 & 2 & 3 & 3 & 3 & 3 & 3 & 2 & 3 & 3 & 3 & 3 & 2 & 2 & 2 & 2 & 3 & 3 & 2 & 64 \\
\hline 5 Amira Rafa Maritza & VA & 4 & 4 & 2 & 4 & 4 & 4 & 2 & 2 & 4 & 4 & 1 & 4 & 4 & 4 & 4 & 4 & 4 & 4 & 4 & 4 & 4 & 4 & 4 & 2 & 89 \\
\hline 6 Anggreta Evalyana Ardeka & $\overline{\mathrm{VA}}$ & 4 & 4 & 2 & 4 & 4 & 2 & 2 & 4 & 2 & 3 & 3 & $\overline{4}$ & 2 & 2 & 4 & $\overline{4}$ & 4 & 4 & 4 & 3 & 3 & 4 & 2 & 3 & 80 \\
\hline 7 Chelsea Althofunnisa A & VA & 4 & 1 & 1 & 4 & 4 & 2 & 4 & 4 & 4 & 4 & 2 & $\overline{4}$ & 2 & 2 & 3 & 4 & 4 & 4 & 4 & 4 & 4 & 3 & 4 & 3 & 83 \\
\hline 8 Dannis Gisella Casyafani & VA & 4 & 2 & 2 & 4 & 3 & 4 & 3 & 4 & 4 & 4 & 1 & 4 & 3 & 2 & 4 & 4 & 4 & 4 & 4 & 4 & 4 & 3 & 4 & 3 & 86 \\
\hline 9 Destya Dew Masyitha & VA & 4 & 2 & 2 & 4 & 2 & 2 & 1 & 4 & 4 & 4 & 4 & 1 & 2 & 2 & 2 & 4 & 4 & 4 & 4 & 4 & 2 & 4 & 4 & 2 & 74 \\
\hline 10 Eksa Ziwana Aryanti & VA & 3 & 3 & 3 & 4 & 4 & 4 & 2 & 4 & 3 & 3 & 4 & 1 & 2 & 2 & 3 & 4 & 4 & 4 & 4 & 3 & 3 & 3 & 4 & 2 & 79 \\
\hline 11 Fadya Miranti Saraswati & VA & 4 & 2 & 2 & 4 & 4 & 3 & 3 & 4 & 2 & 2 & 3 & 1 & 2 & 2 & 2 & 4 & 3 & 2 & 3 & 3 & 2 & 3 & 3 & 2 & 67 \\
\hline 12 Haya Aqila Sasongko & $\mathrm{VA}$ & 4 & 2 & 2 & 4 & 3 & 4 & 3 & 4 & 4 & 3 & 2 & 4 & 4 & 4 & 4 & 4 & 4 & 1 & 3 & 1 & 3 & 4 & 4 & 2 & 80 \\
\hline 13 Keysifa Safa Putri & VA & 4 & 1 & 3 & 4 & 4 & 3 & 3 & 4 & 4 & 2 & 4 & 1 & 2 & 4 & 4 & 4 & 4 & 4 & 4 & 4 & 3 & 4 & 4 & 3 & 85 \\
\hline 14 Khoirunnisa Shafa Anindya & VA & 4 & 1 & 2 & 4 & 4 & 4 & 4 & 4 & 4 & 4 & 1 & 3 & 3 & 3 & 3 & 4 & 4 & 4 & 3 & 4 & 3 & 4 & 4 & 2 & 82 \\
\hline 15 Mufidah & VA & 4 & 3 & 3 & 4 & 4 & 3 & 3 & 4 & 4 & 4 & 1 & 1 & 3 & 4 & 4 & 4 & 4 & 1 & 2 & 1 & 2 & 3 & 4 & 3 & 77 \\
\hline 16 Najjini Millatina Noor F & VA & 2 & 2 & 1 & 2 & 2 & 2 & 2 & 4 & 2 & 3 & 3 & 1 & 1 & 1 & 1 & 1 & 4 & 3 & 3 & 3 & 2 & 2 & 2 & 2 & 53 \\
\hline 17 Nazwa Hikmahtul Maulida & VA & 4 & 3 & 2 & 4 & 4 & 4 & 3 & 4 & 4 & 3 & 2 & 4 & 4 & 4 & 4 & 4 & 4 & 4 & 3 & 4 & 4 & 3 & 3 & 2 & 88 \\
\hline 18 Nildha Faradila & VA & 4 & 4 & 2 & 4 & 4 & 4 & 3 & 4 & 4 & 4 & 1 & 1 & 2 & 4 & 4 & 4 & 4 & 1 & 4 & 1 & 4 & 4 & 4 & 4 & 82 \\
\hline 19 Salma Mahiroh & VA & 4 & 2 & 2 & 4 & 4 & 3 & 2 & 3 & 3 & 2 & 3 & 1 & 4 & 4 & 3 & 4 & 4 & 1 & 3 & 1 & 2 & 2 & 24 & 2 & 70 \\
\hline
\end{tabular}


EDUTECH : Jurnal Inovasi Pendidikan Berbantuan Teknologi Vol. 2 No. 1 Februari 2022, e-ISSN : 2797-0140 | p-ISSN : 2797-0590

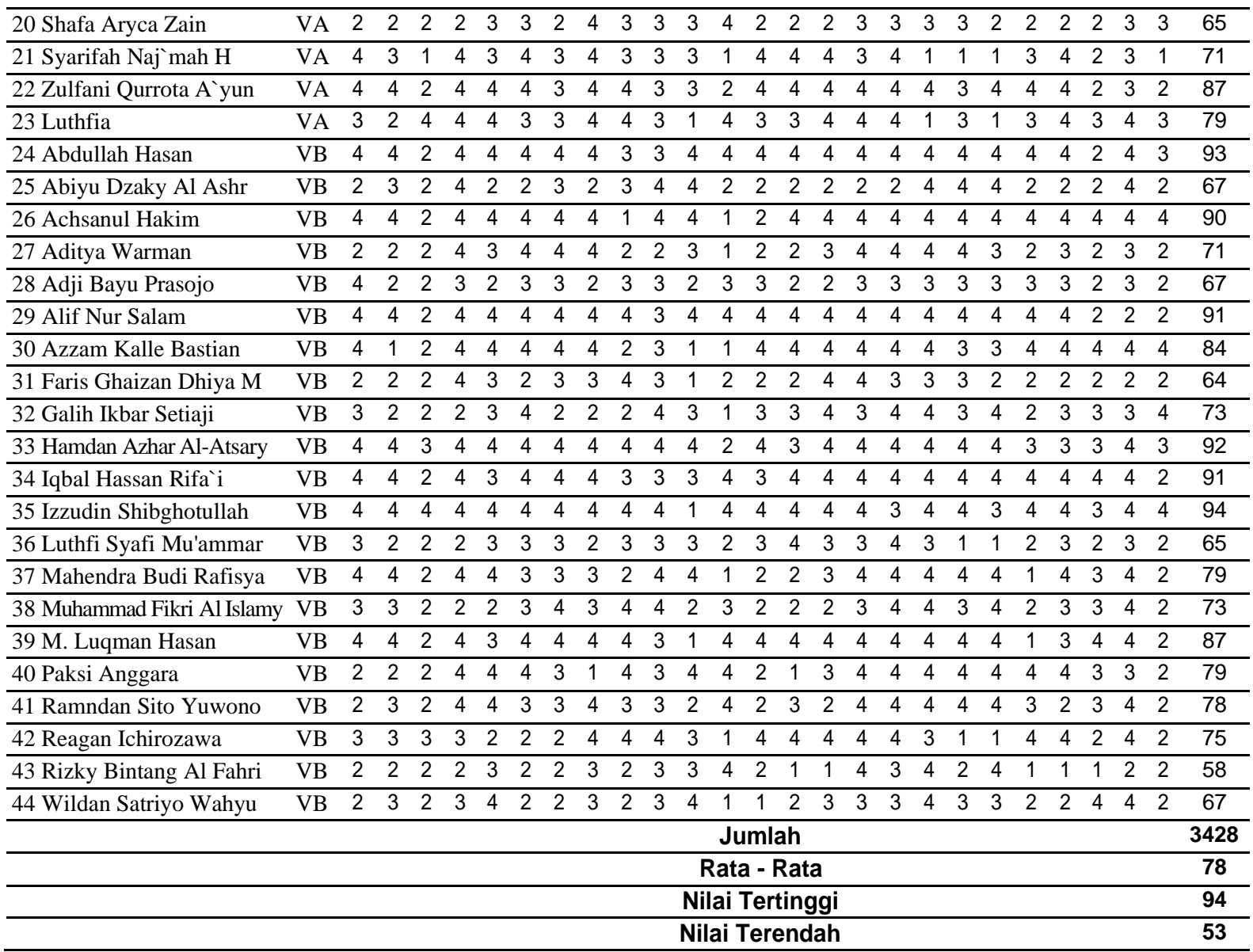

Hasil klasifikasi penelitian ini berupa angket tertutup dengan 4 (empat) alternative jawaban disesuaikan dengan keadaan peserta didik. Berikut akan disajikan hasil tes peserta didik.

Tabel 5. Mencari Mean dan Standar Deviasi Data Kedisiplinan Shalat Lima Waktu Kelas V

\begin{tabular}{ccccccccc}
$\begin{array}{c}\text { No } \\
\text { Kelas }\end{array}$ & $\begin{array}{c}\text { Kelas } \\
\text { Interval }\end{array}$ & $\begin{array}{c}\text { Frekuensi } \\
\text { (f) }\end{array}$ & $\begin{array}{c}\text { Frekuensi } \\
\text { kumulasi }\end{array}$ & $\begin{array}{c}\text { mid point } \\
(\mathbf{d})\end{array}$ & $\boldsymbol{f . d}$ & $(x-x)$ & $(x-x)^{2}$ & $\boldsymbol{f} .(x-x)^{2}$ \\
\hline 1 & $53-59$ & 2 & 2 & 56 & 112 & -21 & 441 & 882 \\
\hline 2 & $60-66$ & 4 & 6 & 63 & 252 & -14 & 196 & 784 \\
\hline 3 & $67-73$ & 9 & 15 & 70 & 630 & -7 & 49 & 441 \\
\hline 4 & $74-80$ & 12 & 27 & 77 & 924 & 0 & 0 & 0 \\
\hline 5 & $81-87$ & 8 & 35 & 84 & 672 & 7 & 49 & 392 \\
\hline 6 & $88-94$ & 9 & 44 & 91 & 819 & 14 & 196 & 1764 \\
\hline & Jumlah & 44 & Jumlah & $\mathbf{3 4 0 9}$ & Jumlah & 4263 \\
\hline
\end{tabular}

Dengan membuat kualitas tingkat kedisiplinan shalat lima waktu peserta didik, dengan stándar deviasi 92,47 sangat baik, standar deviasi 82,47 baik, standar deviasi 72,47 cukup dan standar deviasi 62,47 sangat kurang. 
EDUTECH : Jurnal Inovasi Pendidikan Berbantuan Teknologi

Vol. 2 No. 1 Februari 2022, e-ISSN : 2797-0140 | p-ISSN : 2797-0590

Tabel 6. Tingkat Kualitas Kedisiplinan Shalat Lima Waktu Kelas V

\begin{tabular}{cccc}
\hline Interval & Frekuensi & Prosentase & Kategori \\
\hline 92,47 ke atas & 2 & $\frac{2}{44} \times 100=4,5 \%$ & Sangat Baik \\
\hline $92,47-82,47$ & 13 & $\frac{13}{44} \times 100=29,5 \%$ & Baik \\
\hline $82,47-72,47$ & 16 & $\frac{16}{44} \times 100=36,3 \%$ & Cukup \\
\hline $72,47-62,47$ & 11 & $\frac{11}{44} \times 100=25 \%$ & Kurang \\
\hline Kurang 62,47 & 2 & $\frac{2}{44} \times 100=4,5 \%$ & Sangat Kurang \\
\hline
\end{tabular}

Berdasarkan data di atas rata-rata kedisiplinan shalat lima waktu kelas V di MI Terpadu Lailatul Qodar Sukoharjo Tahun Pelajaran 2020/2021 yaitu 77 dalam kategori cukup, maka jika diprosentasikan dengan 44 responden memberikan kategori prosentase sangat baik 4,5\% dengan frekuensi 2 orang. 29,5\% baik dengan frekuensi 13 orang, 36,3\% cukup dengan frekuensi 16 orang, 25\% kurang dengan frekuensi 11 orang dang 4,5\% sangat kurang dengan frekuensi 2 orang. Untuk kategori sangat kurang dengan faktor penyebabnya adalah saat masuk waktu shalat peserta didik lebih asik bermain handphone dan kurangnya perhatian dan bimbingan dari orang tua untuk menerapkan kedisiplinan shalat lima waktu anak serta ketika sedang sakit tidak menjalankan shalat wajib.

\section{Pembahasan}

Semua data yang digunakan untuk mencari koefesien reabilitas test dengan menggunakan teknik korelasi product moment dari Karl Person. Dan bahwa hasil penelitian rhitung menunjukkan sebesar 0,38797. Selanjutnya untuk mengetahui diterima atau ditolaknya suatu hipotesis perlu dikonsultasikan terlebih dahulu dengan $r$ tabel dengan $\mathrm{N}=44$ pada taraf signifikan $1 \%$ besarnya 0,297 dan pada taraf signifikan $5 \%$ besarnya 0,384 , ternyata rhitung adalah lebih besar dari pada rtabel atau dengan kata lain rhitung $>$ rtabel pada taraf 5\% maka hipotesis alternatif yang berbunyi "Ada pengaruh yang positif antara penggunaan handphone dengan kedisiplinan shalat lima waktu siswa kelas V MI Terpadu Lailatul Qodar Sukoharjo Tahun Pelajaran 2020/2021" diterima atau terbukti kebenaranya. Hasilnya dengan kriteria penafsiran harga koefisien bahwa rhitung=0,387 berada diantara 0,200 sampai dengan 0,400 maka artinya penelitian ini memiliki korelasi yang lemah atau rendah.

Hasil dari penelitian ini mempunyai korelasi yang lemah atau rendah. Artinya, walaupun siswa kelas V di MI Terpadu Lailatul Qodar menggunakan handphone, tetapi mereka tetap disiplin dalam melaksanakan shalat lima waktunya. Hal ini disebabkan karena, di MI Terpadu Lailatul Qodar Sukoharjo mempunyai sebuah program yang diberi nama mutaba'ah harian (sebuah pencatatan kegiatan evaluasi sehari-hari siswa). Dimana siswa diberi lembar mutaba'ah untuk mengontrol / mengecek shalat lima waktu mereka. Dengan adanya lembar mutaba'ah tersebut menjadikan siswa lebih disiplin dan terkontrol dalam melaksanakan shalat lima waktunya, termasuk ketika mereka sedang sakit atau dalam perjalanan.

Penelitian ini menunjukkan kesamaan dengan hasil penelitian Monalisa Mohamad (2018), bahwa alat komunikasi handphone berdampak positif terhadap aktivitas belajar siswa kelas VIII di SMP Negeri 12 Kota Gorontalo. Hal ini terlihat dimana diperoleh nilai thitung $X 1=13,699$, semakin tinggi dampak positif handphone maka semakin meningkat 
aktivitas belajar siswa. Nilai t-hitung dampak negatif X2=-2,291 dan bertanda negatif, hal ini menunjukan bahwa dampak negatif handphone mempunyai hubungan berlawanan arah dengan variabel aktivitas belajar siswa. Dengan tingkat Pvalue X1=0,000, Pvalue X2 $=0,30$ dengan menggunakan batas signifikan $\alpha=0,05$ didapat $t_{\text {tabel }}(95 \% ; 32-1)$ sebesar 1.696. Dari hasil tersebut maka kriteria pengujian yaitu thitung $>t_{\text {tabel }}$ atau $P_{\text {value }}<\alpha$ yang artinya Ho ditolak dan Ha diterima.

Adapun hasil penelitian Rahma Istifadah (2018) menunjukkan, bahwa penggunaan handphone terhadap pesert adidik kelas XI IPS lebih banyak membawa dampak negative daripada dampak positifnya, dampak negative penggunaan handphone pada perilaku peserta didik kelas XI IPS diantaranya adalah banyak peserta didik yang mempunyai handphone, waktu luangnya tersita untuk bermain game, smsa-an, internetan, musikan (bukan untuk belajar) serta tidak memperhatikan guru ketika diterangkan.

Sementara itu hasil penelitian Anis Mutmainah (2019) menunjukkan bahwa gadget sangat mempengaruhi perilaku remaja dalam pelaksanaan ibadah shalat lima waktunya. Dampak positif, yaitu: gadget sebagai media pengingat waktu shalat, gadget sebagai media untuk mencari arah kiblat ketika bepergian, gadget sebagai mediauntuk belajar tata cara shalat dengan benar. Sedangkan dampak negatif, diantaranya: tidak khusyu' dalam shalat, melalaikan waktu shalat dan membantah orangtua. Untuk mengantisipasi dampak negatif agar remaja tidak terlalu jauh terkena dampak negatif dari penggunaan gadget, maka peran orang tua sangat penting dalam pengawasan perkembangan perilaku remaja dalam pelaksanaan ibadah shalat lima waktu.

\section{KESIMPULAN}

Penggunaan handphone kelas V di MI Terpadu Lailatul Qodar Sukoharjo Tahun Pelajaran 2020/2021 digolongkan cukup pada nilai rata-rata 68. Apabila diprosentasekan peserta didik dalam penggunaan handphone sebesar $6,8 \%$ sangat baik dengan frekuensi 3 orang, 27,2\% baik dengan frekuensi 12 orang, 36,3\% cukup dengan frekuensi 16 orang, 20,4\% kurang dengan frekuensi 9 orang dan 9,0\% sangat kurang dengan frekuensi 4 orang. Dan hasil penelitian dari tingkat kedisiplinan shalat lima waktu kelas V di MI Terpadu Lailatul Qodar Sukoharjo Tahun Pelajaran 2020/2021 digolongkan cukup dengan nilai rata-rata 77. Jika diprosentasekan peserta didik yang kedisiplinan shalat lima waktunya sangat baik 4,5\% dengan frekuensi 2 orang, 29,5\% baik dengan frekuensi 13 orang, 36,3\% cukup dengan frekuensi 16 orang, 25\% kurang dengan frekuensi 11 orang dan 4,5\% dengan frekuensi 2 orang.

Setelah dianalisis menggunakan rumus Product Moment hasilnya ada pengaruh yang sangat signifikan antara penggunaan handphone terhadap kedisiplinan shalat lima waktu peserta didik kelas $\mathrm{V}$ dan diterima atau terbukti kebenarannya. Bahwa hasil penelitian r_hitung menunjukkan sebesar 0,38797. Untuk mengetahui diterima atau ditolaknya hipotesis perlu dikonsultasikan terlebih dahulu dengan $r_{-}$tabel dengan $\mathrm{N}=44$ pada taraf signifikan $1 \%$ besarnya 0,297 dan pada taraf signifikan $5 \%$ besarnya 0,384 . Ternyata $r \_$hitung adalah lebih besar dari pada r_tabel atau dengan kata lain r_hitung > r_tabel pada taraf 5\%. Karena rhitung > rtabel maka ada pengaruh yang signifikan antara penggunaan handphone terhadap kedisiplinan shalat lima waktu siswa kelas $\mathrm{V}$ diterima atau terbukti kebenaranya.

\section{DAFTAR PUSTAKA}

Abdurrahman, S. A. (2007). Analisis Korelasi, Regresi, dan Jalur dalam Penelitian . Bandung: Pustaka Setia.

Arikunto, S. (2013). Manajemen Pengajaran. Jakarta: Rineka Cipta.

Faiza, A., \& Firda, S. J. (2018). Arus metamorfosa milenial. Penerbit Ernest.

Monalisa Mohamad, Dampak Penggunaan Alat Komunikasi Handphone terhadap Aktivitas Belajar Siswa Kelas VIII di SMP Negeri 12 Kota Gorontalo, Universitas Negeri Gorontalo, 2015.

Noegroho, A. (2010). Teknologi Komunikasi. Yogyakarta: Graha Ilmu. 
Permana, K. S. (2022). Ketika Pengguna Internet dan Smartphone Terus Meningkat, Android Dominasi Pasar Indonesia dan Dunia. Retrieved january 26, 2022, from https://jabar.tribunnews.com/2019/01/24/ketika-pengguna-internet-dan-smartphoneterus-meningkat-android-dominasi-pasar-indonesia-dan-dunia

Pratama, H. C. (2012). Cyber smart parenting: kiat sukses menghadapi dan mengasuh generasi digital. Bandung: Visi Press Anugerah Indonesia.

Saydam, G. (2006). Sistem Telekomunikasi di Indonesia. Bandung: Alfabeta.

Subando, J. (2020). Statistik Pendidikan Teori dan Aplikasi dengan SPSS. Yogyakarta: Gerbang Media.

Sugiyono. (2013). Metode Penelitian Pendidikan (Pendekatan Kuantitatif, Kualitatif dan $R \& D)$. Bandung: Alfabeta.

Susanto, D. (2018). Penggunaan Smartphone dan Locus of Control : Keterkaitannya Dengan Prestasi Belajar, Kualitas Tidur, dan Subjective Well-Being. Jurnal Psikologi Sosial, 135-136.

Sutarman. (2009). Pengantar Teknologi Informasi. Jakarta: PT Bumi Aksara. 